\title{
Alteration of Fungal Morphology Induced by a Substance from Bacillus cereus
}

\author{
By Y. KOLTIN* AND I. CHORIN-KIRSCH \\ Department of Food and Biotechnology, \\ Technion-Israel Institute of Technology, Haifa, Israel
}

(Accepted for publication 19 March 197I)

\begin{abstract}
SUMMARY
A strain of Bacillus cereus inhibited growth of some fungi and induced the formation of spherical cells. The substance responsible was identified as a thermostable protein active between $\mathrm{pH}$ values of $4^{\circ} 0$ to $7^{\circ} 0$. The substance affected fungi from various classes, but was not equally effective with different fungi. Leakage from cells exposed to the substance was demonstrated. The relation of this substance to the lysins of $B$. cereus is discussed.
\end{abstract}

\section{INTRODUCTION}

Difficulties in incorporation of large molecules during studies on sexual morphogenesis in Schizophyllum commune (Raper, 1966; Raper \& Raper, 1968) have stimulated a search for agents capable of inducing sphaeroplast formation. In the course of this search an inhibitory effect caused by a bacillus was noticed. The bacillus, identified as Bacillus cereus, also induced the formation of spherical cells. Studies were therefore initiated to characterize the inducing substance and to determine its effect on fungi.

Bacillus cereus is known to produce various bacteriolytic substances (lysins) (Greenberg \& Halvorson, I955; Norris, 1957; Bernheimer \& Grushoff, 1967a, $b$; Bernheimer, Grushoff \& Avigad, 1968; Koga \& Kusaka, 1968; Kusaka, 1969). However, it will be shown that the substance inducing the formation of spherical cells in fungi differs from the bacteriolytic substances produced by the same organism.

The induction of spherical cells in fungi by substances of low molecular weight and by unknown agents in the presence of other micro-organisms has been described earlier (e.g. Porter, 1924; Bent \& Morton, 1963). The present study provides a partial characterization of the specific agent formed by Bacillus cereus that induces the formation of spherical cells in fungi, and demonstrates its proteinaceous nature.

\section{METHODS}

Organisms. The bacillus inducing the alteration of fungal morphology was isolated as a contaminant from an agar plate of Schizophyllum commune and identified as Bacillus cereus according to the diagnostic criteria described in Bergey's Manual for Determinative Bacteriology (1957). Other bacilli used were obtained from the collection of the Department of Food and Biotechnology of the Israel Institute of Technology.

The strains of Schizophyllum commune were from the collection of Dr John R. Raper of Harvard University. All other fungi used, with the exception of Collybia, were obtained from Dr M. Chortin, Department of Plant Pathology, Volcani Institute for Agricultural

* Present address: Department of Botany, Tel-Aviv University, Tel Aviv, Israel. 
Research, Beit-Dagon, Israel. Collybia was obtained from the collection of Dr G. Simchen, Genetics Laboratory, Hebrew University, Jerusalem, Israel.

Culture media. The bacteria were grown in a medium (designated henceforth as YE) containing $2 \%(\mathrm{w} / \mathrm{v})$ glucose, $0.5 \%$ yeast extract and $0.5 \%$ peptone. Schizophyllum was grown in complete medium (CM) and minimal medium (MM) described by Raper \& Miles (1958). All other fungi used in the study were grown on potato dextrose agar (PDA).

Production and characterization of the inducing substance. Cultures of Bacillus cereus were grown in $250 \mathrm{ml}$. flasks containing YE broth on a rotary shaker at $30^{\circ}$. The flasks were inoculated with $\mathrm{I} \mathrm{ml}$. of a suspension of a $16 \mathrm{~h}$. culture. Twenty $\mathrm{h}$. after inoculation the broth was centrifuged (25,000 $\mathrm{g}$ for I $5 \mathrm{~min}$.) and the supernatant was assayed for activity after filtration through a Millipore filter $(0 \cdot 45 \mu \mathrm{m}$.).

Activity was assayed as follows: One $\mathrm{ml}$. samples of the supernatant were distributed in sterile test tubes into which agar blocks containing fungal mycelium were introduced. After incubation at $25^{\circ}$ for a minimum of $10 \mathrm{~h}$. the mycelium was examined microscopically for the presence of spherical cells.

Characterization of the active substance followed its separation from the medium by ammonium sulphate fractionation and dialysis of the precipitate against $\mathrm{IO}^{-3} \mathrm{M}$-citratephosphate buffer $\left(\mathrm{pH}_{5} .6\right)$ and in some instances following chromatography on Sephadex G-200 with the same buffer.

Tests for induction of leakage from the cells were performed with prelabelled germlings of Schizophyllum. The spores were obtained from a fruiting dikaryon and the germlings were labelled by incorporation of $\left[{ }^{14} \mathrm{C}\right]$ glucose, $\left[{ }^{3} \mathrm{H}\right]$ phenylalanine, or $\left[{ }^{3} \mathrm{H}\right]$ deoxyuridine during growth in MM in the presence of each of the labelled compounds. To increase the efficiency of incorporation 'cold' glucose and asparagine were omitted from the medium when labelled glucose and phenylalanine respectively were used. After $54 \mathrm{~h}$. growth in the presence of the labelled compound the germlings were harvested on a Millipore filter, washed with the corresponding 'cold' compound and placed in a scintillation vial into which $2 \mathrm{ml}$. of YE, or YE and the substance inducing the alteration of fungal morphology (MAS), was added. The vials with the germlings were incubated at $25^{\circ}$ and the leakage of labelled compounds from the cells was determined at various times by measuring the radioactivity, in filtered $0.1 \mathrm{ml}$. samples of YE and YE+MAS, in a liquid scintillation counter (Packard Model 33I0).

\section{RESULTS}

Effect of MAS on various micro-organisms. Bacillus cereus inhibited growth of Schizophyllum commune and induced the formation of spherical cells; the effect was not limited to the terminal cells. Growth inhibition and spherical cell formation on exposure to MAS were also shown by Alternaria tenuis, Aspergillus niger, Claviceps paspali, Fusarium moniliforme, Pullularia sp. and Trichoderma viride. However, Aspergillus tereus, Collybia velutipes, Nematoctonus sp., Penicillium notatum and Phytophthora parasitica were insensitive to MAS. Thus not all fungi were equally affected, and the induction of spherical cells occurred among representatives of different classes. Among the organisms tested F. moniliforme was extremely sensitive (Pl. I).

To determine if inhibition of growth and the induction of spherical cell formation in Schizophyllum commune was exclusive to Bacillus cereus the effect of various bacilli was examined. Bacillus subtilis, B. mycoides and B.thuringiensis neither inhibited the growth of the fungus nor induced the formation of spherical cells. Bacillus megaterium and B. polymyxa inhibited the growth of the fungus but did not induce the formation of spherical cells. Only 
the $B$. cereus isolated originally from the plates of Schizophyllum, and other isolates of $B$. cereus from the bacterial stock collection inhibited the growth of $S$. commune and induced the formation of spherical cells.
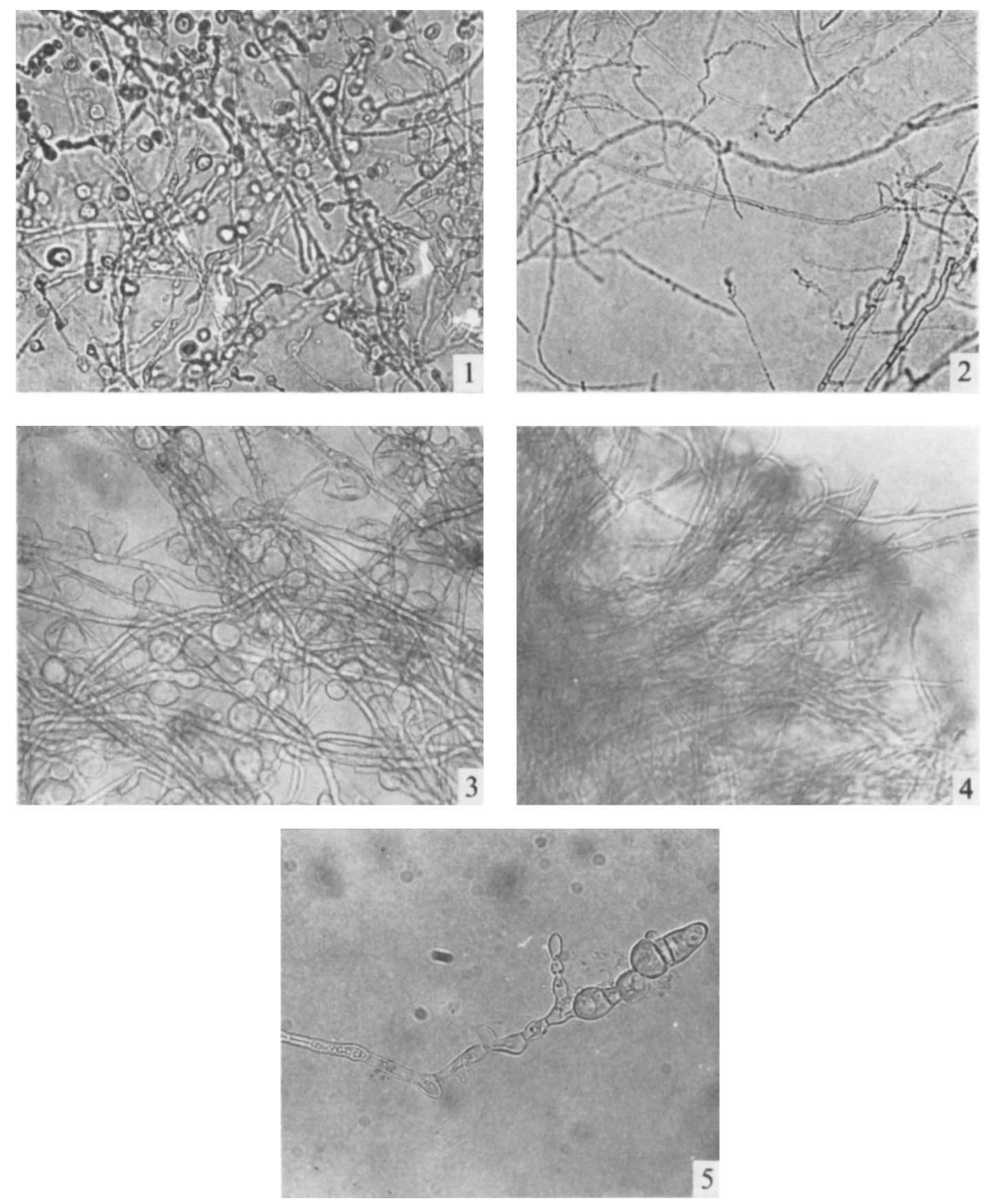

EXPLANATION OF PLATE

The effect of the substance (MAS) produced by Bacillus cereus on fungal mycelium.

Fig. I. Schizophyllum commune exposed to MAS.

Fig. 2. Normal mycelium of Schizophyllum commune.

Fig. 3. Fusarium moniliforme exposed to MAS.

Fig. 4. Normal mycelium of Fusarium moniliforme.

Fig. 5. Reformation of the mycelium of Schizophyllum commune from detached cells after long exposure to MAS. 
Nature and properties of $M A S$

A cell-free filtrate of the medium in which the Bacillus was grown contained the active substance. The substance was precipitated by ammonium sulphate. Activity was distributed between the precipitate and the supernatant at $50 \%$ extinction, but only in the precipitate of the $70_{i}^{\circ}$ fraction.

The molecular size was not small, as the substance was non-dialysable. Furthermore, in column chromatography on Sephadex G-200, with Blue Dextran and cytochrome $c$ as markers, it was eluted nearer to Blue Dextran (Fig. I). The substance was excluded (i.e. was in the first fraction) from a Sephadex G-I00 column. Thus the molecular weight of the active substance is probably within the range of 1 to $2 \times 10^{5}$.

Activity was recovered in fractions with negligible extinction at $260 \mathrm{~nm}$. and maximal extinction $(E)$ at $280 \mathrm{~nm}$. The ammonium sulphate fractionation and the extinction characteristics of the active fractions thus suggest that MAS was a protein.

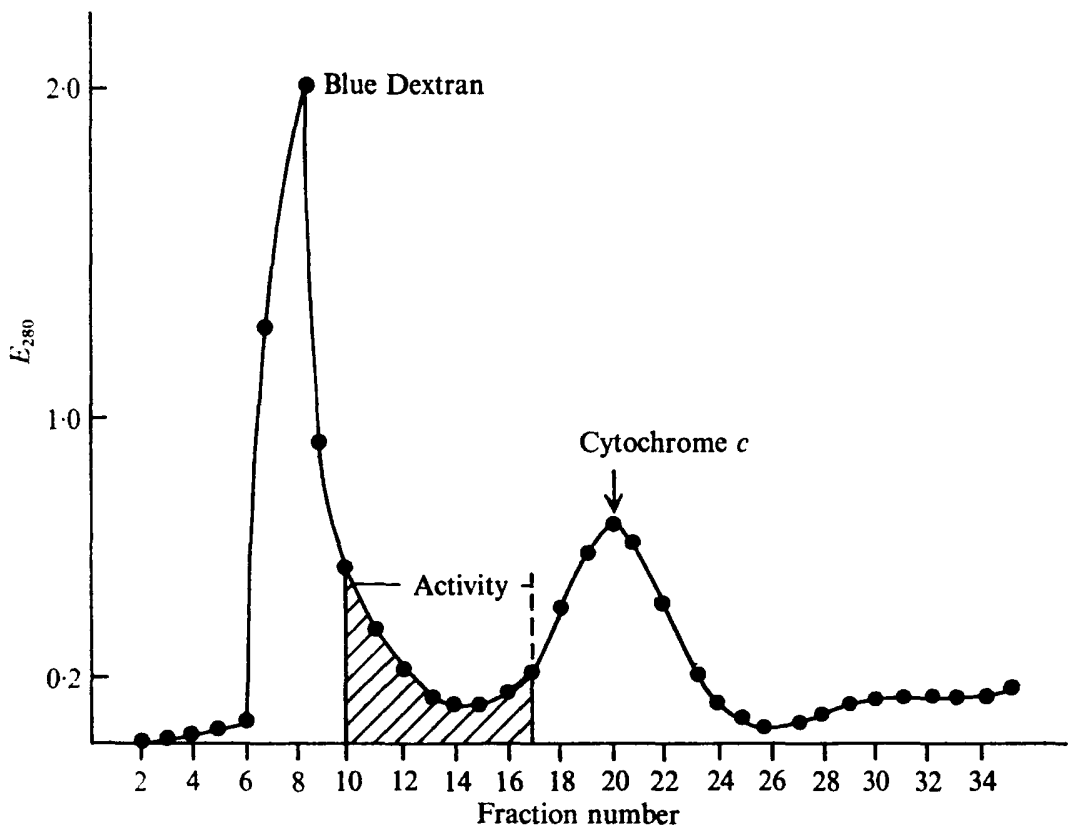

Fig. I. Molecular exclusion chromatography of the fraction precipitated by $\left(\mathrm{NH}_{4}\right)_{2} \mathrm{SO}_{4}(70 \%$ saturation) on a $30 \mathrm{~cm}$. Sephadex G-200 column (10-3 $\mathrm{M}$-citrate-phosphate buffer, $\left.\mathrm{pH} 5^{\cdot 6}\right)$. Cytochrome $c$ was characterized by its extinction spectrum.

In tests at temperatures between $4^{\circ}$ and $55^{\circ}$ the substance was active between $12^{\circ}$ and $37^{\circ}$. However, whereas at the lowest temperature tested the mycelium of the indicator fungus (Schizophyllum commune) was viable, this was not the case at the highest temperature. Only following clarification of the biochemical effect of the substance will it be possible to determine the upper limit of activity.

In tests at a range of $\mathrm{pH}$ values from 3.0 to 8.5 at intervals of 0.5 units the substance was active between $\mathrm{pH} 4.0$ and $\mathrm{pH}_{7}{ }^{\circ} \mathrm{O}$ with a decline in activity at the two extremes. Maximal activity was obtained at $\mathrm{pH} 5 \cdot 0$ and 5.5 .

Although the precipitation and extinction characteristics suggest that MAS is a protein, it remained active after exposure to $100^{\circ}$ for $70 \mathrm{~min}$. The stability at this temperature is 
reminiscent of spore proteins (for review see Kornberg, Spudich, Nelson \& Deutscher, I968). However, the degree of inactivation of MAS by high temperature cannot be accurately quantified before defining a biochemical reaction in which it participates. It is conceivable that the substance is a complexed protein in which the protein portion of the molecule is stabilized. Additional indications to this effect were found in tests to determine the effect of proteolytic enzymes on MAS. After treatment with trypsin $(400 \mu \mathrm{g} . / \mathrm{ml}$.) and chymotrypsin (I00 $\mu \mathrm{g} . / \mathrm{ml}$.) for $5 \mathrm{~h}$. at $\mathrm{pH} 8.5$ no discernible decline of activity was observed. MAS was totally inactivated by pronase ( $100 \mu \mathrm{g} . / \mathrm{ml}$.) only after exposure to the proteolytic enzyme for $5 \mathrm{~h}$. at $\mathrm{pH} 8.5$.

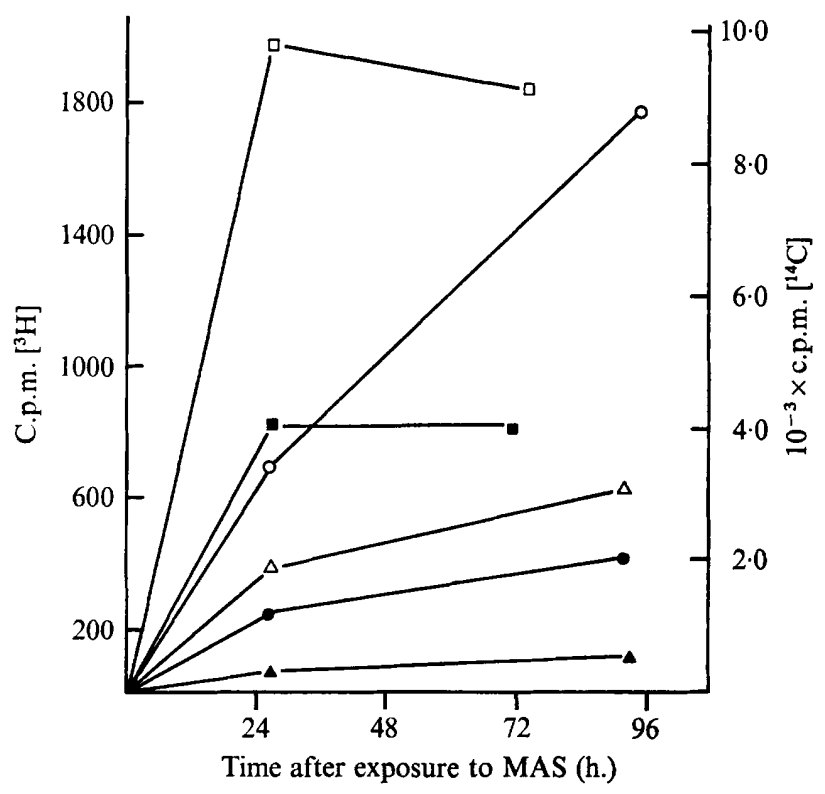

Fig. 2

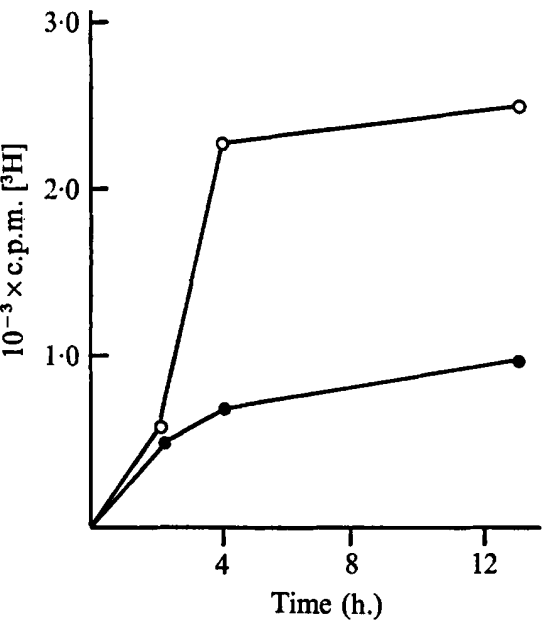

Fig. 3

Fig. 2. Leakage from cells of Schizophyllum commune induced by MAS. $\square$, Prelabelled with $\left[{ }^{14} \mathrm{C}\right]$ glucose and exposed to MAS; $\mathbf{n}$, control. $\mathrm{O}$, Prelabelled with $\left[{ }^{3} \mathrm{H}\right]$ phenylalanine and exposed to MAS;, , control. $\triangle$, Prelabelled with $\left[{ }^{3} \mathrm{H}\right]$ deoxyuridine and exposed to MAS; $\Delta$, control.

Fig. 3. Time of induction of leakage from cells of Schizophyllum commune labelled with $\left[{ }^{3} \mathrm{H}\right]$ phenylalanine. $O$, Cells exposed to MAS; 0 , control.

Cholesterol and ergosterol (Io to $100 \mu \mathrm{g} . / \mathrm{ml}$.) had no effect on the activity of MAS. However, the surface-active agents Tween 40 and Tween $80(0.1$ to $I \cdot 0 \%, v / v)$ inhibited the activity of MAS.

The effect of MAS on fungal and bacterial cells. Long exposure of mycelium of Schizophyllum to MAS ( 5 to Io days) resulted in the dissociation of the spherical cells from the mycelium. Groups of these were found in the supernatant after slow centrifugation $(2000 \mathrm{~g}$ for $5 \mathrm{~min}$.). Dissociation was extensive if the mycelium was kept in the presence of MAS on a rotary shaker. The individual cells could germinate and reform the mycelium (PI. I). If germination occurred in the presence of MAS new spherical cells were formed; if germination occurred in the absence of MAS normal growth was resumed. Only some spherical cells exhibited osmotic sensitivity to distilled water. Addition of up to $10^{-2} \mathrm{M}-E D T A$ did not increase the proportion of cells sensitive to such osmotic conditions. 
By the use of various metabolic precursors it was shown that MAS induced leakage from the cells of Schizophyllum (Fig. 2, 3) within 2 h. of exposure (Fig. 3). The results of such a test for leakage often reflect the state of the membrane. However, the instability of the membrane may not have resulted from a direct effect of MAS, but rather from an alteration of wall structure induced by MAS.

Because various lysins isolated from Bacillus cereus were reported to induce lysis of $B$. cereus and B. subtilis (Bernheimer et al. 1968; Kusaka, 1969) the effect of MAS on bacteria of these two species was examined to evaluate the relations of MAS to the various lysins. Exposure of the bacteria to MAS for $24 \mathrm{~h}$. did not affect the viability and therefore did not induce lysis.

\section{DISCUSSION}

The substance isolated from Bacillus cereus, which induced formation of spherical cells of fungi, differed from the bacteriolytic substances associated with spore-forming aerobic bacteria (Greenberg \& Halvorson, I955; Norris, I957; Koga \& Kusaka, 1968; Kusaka, I969) in that: $(a)$ it was thermostable, $(b)$ its effect was shown in the presence of sterols and $(c)$ it did not induce lysis in bacteria. The only common property found thus far is the proteinaceous nature of both the lysins and MAS.

The effects of MAS on fungi were the induction of formation of spherical cells, the dissociation of the mycelium and leakage from the cells. However, osmotic sensitivity was not uniform among the spherical cells, which suggested that these cells retained at least part of the cell wall and thus retained their rigidity. The effect of MAS on fungal cell wall is being currently examined by both chemical and cytological analysis. Although it has recently been shown that cells of temperature-sensitive mutants of Aspergillus nidulans with defective synthesis of amino sugars assume a spherical shape (Cohen, Katz \& Rosenberger, 1969) the effect of MAS may be of a degradative nature rather than inhibition of synthetic processes since the effect was not restricted to the terminal cells.

The advice and criticism of Dr R. Zelikson are gratefully acknowledged.

\section{REFERENCES}

Bent, K. J. \& Morton, A. G. (1963). Formation and nature of swollen hyphae in Penicillium and related fungi. Transactions of the British Mycological Society 46, 401-408.

Bergey's Manual of Determinative Bacteriology (1957), 7th edn. Baltimore, Maryland: The Williams \& Wilkins Co.

Bernheimer, A. W. \& Grushoff, P. (1967a). Extracellular hemolysins of aerobic sporogenic bacilli. Journal of Bacteriology 93, I $54 \mathrm{I}-\mathrm{I} 543$.

Bernheimer, A. W. \& Grushoff, P. $(1967 b)$. Cereolysin: Production, purification and partial characterization. Journal of General Microbiology 46, 143-149.

Bernheimer, A. W., Grushoff, P. \& AVigad, L. S. (I 968). Isoelectric analysis of cytolytic bacterial proteins. Journal of Bacteriology 95, 2439-244I.

Cohen, J., Katz, D. \& Rosenberger, R. F. (1969). Temperature-sensitive mutant of Aspergillus nidulans lacking amino sugars in its cell wall. Nature, London 224, 71 3-71 5.

Grefnberg, T. A. \& Halvorson, H. O. (1955). Studies on an autolytic substance produced by an aerobic spore-forming bacterium. Journal of Bacteriology 69, 45-50.

KOGA, Y. \& KUSAKA, I. ( 1968). Involvement of autolysis of cytoplasmic membrane in the process of autolysis of Bacillus cereus. Journal of General Microbiology 53, 253-258.

Kornberg, A., Spudich, J. A., Nelson, D. L. \& Deutscher, M. P. (1968). Origin of proteins in sporulation. Annual Review of Biochemistry 37, $5 \mathrm{I}-78$.

KUSAKA, I. (1969). Membrane lytic factor in Bacillus cereus. Journal of Fermentation Technology 47, 7 IO-7 3. 
NoRRIS, J. R. (1957). A bacteriolytic principle associated with cultures of Bacillus cereus. Journal of General Microbiology 16, I-8.

PORTER, C. L. (1924). Concerning the character of certain fungi as exhibited by their growth in the presence of other fungi. American Journal of Botany II, I68-188.

RaPeR, J. R. (1966). Genetics of Sexuality in Higher Fungi. New York: The Ronald Press.

RAPER, J. R. \& Miles, P. G. (1958). The genetics of Schizophyllum commune. Genetics, 43, 530-546.

RAPER, J. R. \& RAPER, C. A. (1968). Genetic regulation of sexual morphogenesis in Schizophyllum commune. Journal of the Elisha Mitchell Scientific Society 84, 267-273. 